\title{
Dry Rot of Rutabaga Caused by Fusarium avenaceum
}

\author{
Rick D. Peters ${ }^{1}$ \\ Agriculture and Agri-Food Canada, Crops and Livestock Research Centre, \\ 440 University Avenue, Charlottetown, PE, Canada C1A 4N6
}

Tharcisse Barasubiye

Agriculture and Agri-Food Canada, Eastern Cereal and Oilseed Research Centre, 960 Carling Avenue, Ottawa, ON, Canada K1A 0C6

\section{Joanne Driscoll \\ Prince Edward Island Horticultural Association, P.O. Box 2232, Charlottetown, PE, Canada C1A $8 B 9$}

Additional index words. Brassica napus, swede turnip, crucifers, fungal diseases

\begin{abstract}
The rutabaga, also known as the swede turnip, is grown on $\approx 2000$ ha in Canada. During the spring of 2006, a grower in Prince Edward Island noticed an advanced level of decay in his stored rutabagas (cv. Thompson Laurentian). About $80 \%$ of the stored crop was affected. Lesions on the surface of affected roots were circular to ovate and ranged in size from 10 to $50 \mathrm{~mm}$. The lesions were light brown, with dark borders and some concentric zones evident near the perimeter of the affected tissue. Root tissue within the lesions was shrunken and often wrinkled. Sectioning the root through the lesion revealed an internal advancing dry rot, with an irregular border and cavities that contained white mycelium. Isolation from diseased tissues yielded fungal cultures, which were determined to be Fusarium avenaceum using morphological and molecular criteria. Successful completion of Koch's postulates determined that $F$. avenaceum was indeed the causal agent of rutabaga dry rot. To the authors' knowledge, this is the first report of $F$. avenaceum causing disease in rutabaga in Prince Edward Island, and likely only the second observation of its occurrence in North America. Dry rot, incited by $F$. avenaceum, may need to be considered as part of the spectrum of postharvest pathogens of rutabaga.
\end{abstract}

The rutabaga [Brassica napus L. (Napobrassica group)], also known as the swede turnip, is a member of Brassicaceae, and in North America is predominantly grown in California, Colorado, Wisconsin, and Minnesota, as well as several Canadian provinces. In Canada, production occurs on $\approx 1500$ ha, with the majority in Ontario (41\%), Quebec (29\%), and the Atlantic provinces (25\%) (Statistics Canada, 2007). Prince Edward Island rutabaga production accounts for $\approx 13 \%$ of total production (Statistics Canada, 2007). Much of the crop is stored, sometimes for periods of up to 9 months. Rutabagas are commonly stored at temperatures near $0{ }^{\circ} \mathrm{C}$ to reduce postharvest decay, and at a relative humidity greater than $95 \%$ to reduce root shrinkage. Rutabagas are particularly susceptible to bruising, especially during mechanical harvesting, which can lead to the development of rot in storage. For this

\footnotetext{
Received for publication 1 Dec. 2006. Accepted for publication 8 Feb. 2007.

Agriculture and Agri-Food Canada contribution no. 1072.

We thank Dr. Keith Seifert, Agriculture and AgriFood Canada, Eastern Cereal and Oilseed Research Centre for his assistance in micromorphological identification of Fusarium avenaceum.

${ }^{1}$ To whom reprint requests should be addressed; e-mail petersr@agr.gc.ca
}

reason, much of the crop in some production areas, including Prince Edward Island, is hand-harvested.

During the spring of 2006, a grower in Prince Edward Island noticed an advanced level of decay in his stored rutabagas (cv. Thompson Laurentian). These rutabagas (9 ha) had been harvested in mid October (typical harvest period in Prince Edward Island). After shipments to early markets, $\approx 122,500 \mathrm{~kg}(30 \%$ of the harvested crop) was placed into storage. Symptoms of disease were first noticed toward the end of January and, by mid February, $80 \%$ of the stored crop was affected and ultimately unmarketable. Lesions on the surface of affected roots were circular to ovate and ranged in size from 10 to $50 \mathrm{~mm}$ (Fig. 1A). The lesions were light brown, with dark borders and some concentric zones evident near the perimeter of the affected tissue. Root tissue within the lesions was shrunken and often wrinkled. Sectioning the root through the lesion revealed an internal advancing dry rot, with an irregular border and cavities that contained white mycelium (Fig. 1B).

Sections of root tissue $(10 \times 5 \times 3 \mathrm{~mm})$ were excised from the margins of lesions from five diseased rutabagas with a sterile scalpel. The sections were then surface sterilized in $0.6 \%$ sodium hypochlorite for $2 \mathrm{~min}$, rinsed twice in sterile distilled water, and blotted dry on sterile filter paper (Whatman no. 4, Whatman, Florham Park, N.J.). Tissue pieces were then plated onto one-quarter strength potato dextrose agar (PDA) in small Petri dishes $(60 \times 15 \mathrm{~mm}$; Fisher Scientific Co., Nepean, Ont.). Petri dishes were incubated in the dark at $22{ }^{\circ} \mathrm{C}$ for $7 \mathrm{~d}$. After incubation, fungal growth was noted emanating from all tissue sections. Hyphal tips from the margins of actively growing cultures were removed with a sterile probe and plated onto PDA to generate pure cultures.

All isolates were morphologically similar, so one was chosen for more detailed identification. To identify the fungal isolate, the following procedures were carried out using DNA sequencing methods and micromorphological observations. Pure cultures were grown in 9-cm polystyrene Petri dishes on PDA for $5 \mathrm{~d}$ at $22{ }^{\circ} \mathrm{C}$ in the dark. Fungal mycelia were scraped from the surface of the agar using a sterilized scalpel, and total genomic DNA was extracted using the DNeasy Plant Mini Kit (QIAGEN, Valencia, Calif.) according to the manufacturer's instructions. One microliter of aliquot was then analyzed on a $1.5 \%$ agarose gel in $0.5 \times$ Tris-borate-ethylenediamine tetraacetic acid (EDTA) buffer to estimate the concentration and quality of the DNA.

Specific primer sets were used to amplify a 700-bp fragment of the translation elongation factor $\alpha$ gene $(E F 1-\alpha)$ region (Barasubiye et al., 2005). Polymerase chain reaction (PCR) amplification was carried out in an Eppendorf cycler (Brinkmann Instruments, Westbury, N.Y.). Each reaction mixture contained $10 \mathrm{ng}$ (usually $1 \mu \mathrm{L}$ ) diluted template genomic DNA, $1 \times$ Titanium Taq buffer $(10 \times), 3.5 \mathrm{mM} \mathrm{MgCl}_{2}$ included in $10 \times$ buffer, $0.1 \mathrm{mM}$ each of four deoxyribonucleotide triphosphates, $0.08 \mu \mathrm{M}$ of each primer, and $1 \mathrm{U}$ of Titanium Taq DNA polymerase in a total of $10 \mu \mathrm{L}$. An initial denaturation step of $95{ }^{\circ} \mathrm{C}$ for $3 \mathrm{~min}$ was followed by 34 amplification cycles of denaturation (the first five cycles at $95^{\circ} \mathrm{C}$ for $45 \mathrm{~s}$, annealing at $68^{\circ} \mathrm{C}$ for $45 \mathrm{~s}$, and extension at $72{ }^{\circ} \mathrm{C}$ for $90 \mathrm{~s}$ ). Cycles 6 to 10 and 11 to 34 used the same parameters except that the annealing temperature was 66 and $62{ }^{\circ} \mathrm{C}$, respectively. After the 34 cycles were completed, the amplicons were incubated for an additional $8 \mathrm{~min}$ at $72^{\circ} \mathrm{C}$ for a final extension. A negative control (without DNA template) was used to test for DNA contamination of reagents and reaction mixtures. To estimate the concentration and quality of PCR, $1 \mu \mathrm{L}$ amplicon from the PCR reaction was run on a $1.5 \%$ agarose gel with $0.5 \mu \mathrm{g}$ ethidium bromide/milliliter and $0.5 \times$ Tris borate EDTA buffer for $45 \mathrm{~min}$. DNA bands were visualized on an ultraviolet transilluminator.

Sequencing of the EF1- $\alpha$ template was performed using the BigDye Terminator V2.0 ready reaction kit from Applied Biosystems (Forster City, Calif.) and $0.5 \times$ reactions. An estimated 10 to $20 \mathrm{ng}$ of each amplicon was sequenced in both directions using the same primers described earlier for PCR. Sequencing reactions were analyzed with the ABI 3100-Avant automated sequencer 

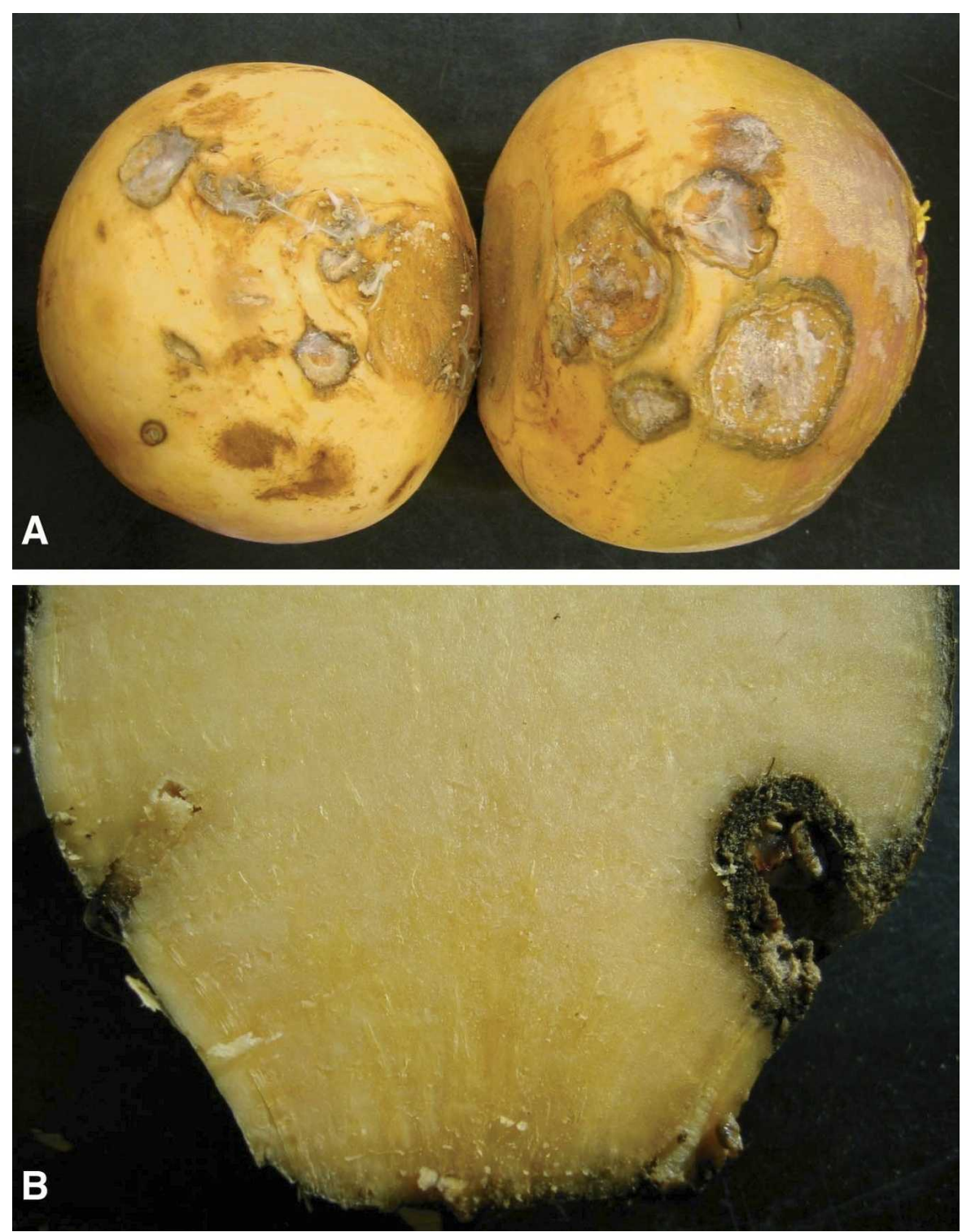

Fig. 1. (A) External symptoms of dry rot of rutabaga incited by Fusarium avenaceum. (B) Internal decay of rutabaga after artificial inoculation of wounded roots with $F$. avenaceum. Note the control inoculation (agar disk only) on the left.

(Applied Biosystems-Hitachi). Contigs were assembled and sequences were edited using SeqMan version 6.1 (DNASTAR, Madison, Wisc.). The sequence was deposited in GenBank (accession no. EF105293) and it was used for searching for similar sequences in various databanks, including FUSARIUM-ID v. 1.0 (Geiser et al., 2004) and GenBank using the BLASTn program for nucleotidenucleotide analysis (version 2.0, National Center for Biotechnology Information, U.S. National Institutes of Health, Bethesda, Md.). Using the BLASTn program, the five most significant sequences of Fusarium avenaceum (accession nos. AJ543520, AJ543519, AJ543518, AJ543517, and AJ543516) with $99.8 \%$ similarity to our strain were considered to confirm identity. A score higher than 1218 for the top five sequences was obtained, and the expectation $\mathrm{E}$ value was 0.0 .

The culture was also grown on Spezieller Nährstoffarmer Agar (Nirenberg, 1981) with of PDA (control). The other two wounds on each root were each inoculated with a disk of PDA containing active mycelium of $F$. avenaceum taken from the margin of a 7-d-old culture growing on PDA. After inoculation, the excised root tissue plugs were placed back into the cavities created by their extraction to seal the wounds. Each rutabaga was then placed in a paper bag (Harvest Gold, $4.54 \mathrm{~kg}$; PEI Bag Co. Ltd., Summerside, PEI) and stored in the dark at $10{ }^{\circ} \mathrm{C}$ and $95 \%$ relative humidity in a vegetable storage facility for 5 weeks.

After 5 weeks in storage, the inoculated rutabagas were examined for external and internal symptoms of disease. Symptoms of disease were like those seen in the original diseased samples, including the development of typical dry rot in internal tissues (Fig. 1B). Control wounds inoculated with PDA disks only developed no disease symptoms (Fig. 1B). Isolations from diseased lesions using the same protocols described previously always yielded isolates of $F$. avenaceum, as determined by micromorphological observations (shape of macroconidia).

Fusarium avenaceum is a ubiquitous soilborne fungus and occurs on a wide range of plant hosts (Booth, 1971). It is widely known as one of the causal agents of Fusarium dry rot of potato (Satyaprasad et al., 1997) and, in the Maritime region of Canada, is the cause of close to $15 \%$ of the dry rot encountered by growers (R.D. Peters, unpublished data). References to $F$. avenaceum as a pathogen of cruciferous crops are somewhat limited, but $F$. avenaceum has been found to be a pathogen of canola (Brassica napus L.) (Lange et al., 2000; Tahvonen et al., 1984), stored broccoli (B. oleracea var. italica Plenck.) (Mercier et al., 1991), and cabbage (B. oleracea var. capitata L.) in storage (Geeson, 1983), as well as the cause of head rot of cabbage in the field (Dillard and Cobb, 2006; Dillard et al., 2004). To our knowledge, this is the first report of $F$. avenaceum causing disease in rutabaga in Prince Edward Island, and likely only the second observation of its occurrence in North America, after a brief reference to surface rot, presumably incited by $F$. avenaceum, of swede turnips in Nova Scotia in 1961 (Creelman, 1962). Storage rot of rutabaga incited by $F$. avenaceum is not described in any of the recent guides to diseases of cruciferous crops (Howard et al., 1994; Rimmer et al., 2006). The incidence of this disease in North America is uncertain, and although likely low, the severity of disease development in the storage of concern in this study would indicate that it may need to be considered as part of the spectrum of postharvest pathogens of rutabaga.

Fusarium species are ubiquitous in soil and often able to colonize plant wounds, sometimes leading to disease development. As mentioned, rutabagas are susceptible to bruising during harvest operations, which in turn also makes them susceptible to opportunistic wound pathogens. Although the diseased rutabagas described here were hand-harvested, root damage can still occur when harvested 
roots are gathered and tossed into crates or handled before entering storage. In addition, tractors used to apply pest control products can sometimes damage roots before harvest. Minimizing root injury would be a key cultural practice to reduce storage rot, in addition to maintaining low storage temperatures. Thiabendazole has excellent efficacy for control of dry rot of potato incited by $F$. avenaceum (Hide et al., 1992; Satyaprasad et al., 1997) and is available as a postharvest application; however, this product is currently not registered for use on rutabaga. Chemical control may become an option in situations when Fusarium dry rot of rutabaga becomes entrenched.

\section{Literature Cited}

Barasubiye, T., K. Seifert, A. Tenuta, S. Rioux, T. Anderson, T. Welacky, and C.A. Levesque. 2005. Monitoring of Fusarium species in soybean roots by DNA array hybridization. Phytopathology 95:S59.

Booth, C. 1971. The genus Fusarium. Commonwealth Mycological Inst., Kew, UK.

Creelman, D.W. 1962. Summary of the prevalence of plant diseases in Canada in 1961: Diseases of vegetables and field crops. Can. Plant Dis. Surv. 42:46-71.
Dillard, H.R., R.R. Bellinder, and D.A. Shah. 2004. Integrated management of weeds and diseases in a cabbage cropping system. Crop Prot. 23:163-168.

Dillard, H.R. and A.C. Cobb. 2006. Fusarium avenaceum, a new fungal head rot of cabbage in New York. Phytopathology 96:530.

Howard, R.J., J.A. Garland, and W.L. Seaman (eds.). 1994. Diseases and pests of vegetable crops in Canada. Can. Phytopathol. Soc. and Entomol. Soc. Can., Ottawa.

Geeson, J.D. 1983. Brassicas, p. 125-156. In: C. Dennis (ed.). Post-harvest pathology of fruits and vegetables. Academic Press, London.

Geiser, D.M., M. Delmar Jimenez-Gasco, S. Kang, I. Makalowska, N. Veeraraghavan, T.J. Ward, N. Zhang, G.A. Kuldau, and K. O’Donnell. 2004. FUSARIUM-ID v.1.0: A DNA sequence database for identifying Fusarium. Eur. J. Plant Pathol. 110:473-479.

Gerlach, W. and H. Nirenberg. 1982. The genus Fusarium: A pictorial atlas. Mitt. Biol. Bund. Land- u. Forstw. Berlin-Dahlem 209:1-406.

Hide, G.A., P.J. Read, and S.M. Hall. 1992 Resistance to thiabendazole in Fusarium species isolated from potato tubers affected by dry rot. Plant Pathol. 41:745-748.

Lange, R.M., L.M. Harrison, and P.D. Kharbanda. 2000. A new Fusarium wilt of canola in Alberta, Canada in 1999. American Phytopathological Society, 2000 Pacific Division meeting abstracts. Publication no. P-2000-
0033-PCA. 27 Mar. 2007. <www.apsnet.org/ meetings/div/pc00abs.asp >

Mercier, J., J. Makhlouf, and R.A. Martin. 1991. Fusarium avenaceum, a pathogen of stored broccoli. Can. Plant Dis. Surv. 71:161162.

Nelson, P.E., T.A. Toussoun, and W.F.O. Marassas. 1983. Fusarium species, an illustrated manual for identification. Pennsylvania State University, University Park, Pa.

Nirenberg, H.I. 1981. A simplified method for identifying Fusarium species occurring on wheat. Can. J. Bot. 59:1599-1609.

Rimmer, S.R., V.I. Shattuck, and L. Buchwaldt (eds.). 2006. Compendium of Brassica diseases. APS Press, St. Paul, Minn.

Satyaprasad, K., G.L. Bateman, and P.J. Read. 1997. Variation in pathogenicity on potato tubers and sensitivity to thiabendazole of the dry rot fungus Fusarium avenaceum. Potato Res. 40:357-365.

Statistics Canada. 2007. Fruit and vegetable production. February 2007. Catalogue no. 22-003XIB, Vol. 75, no. 2, Statistics Canada, Agriculture Division, Crops Section, Ottawa, Ontario. 40 pp. 27 Mar. 2007. <www.statcan.ca/english/ freepub/22-003-XIB/22-003-XIB2006002.pdfs.

Tahvonen, R., J. Hollo, A. Hannukkala, and A. Kurpa. 1984. Rhizoctonia solani damping-off on spring turnip rape and spring rape Brassica spp. in Finland. J. Agr. Sci. Fin. 56:143154. 